\title{
Stress granules inhibit apoptosis by reducing ROS production, but this phenomenon is nullified by HTLV-1 Tax
}

\author{
Masahiko Takahashi", Masaya Higuchi, Masahiro Fujii \\ From 16th International Conference on Human Retroviruses: HTLV and Related Viruses \\ Montreal, Canada. 26-30 June 2013
}

Human T-cell leukemia virus type 1 (HTLV-1) is the etiological agent of adult T-cell leukemia (ATL), and the viral oncoprotein Tax plays key roles in immortalization of human T-cells and leukemogenesis. Here, we identified the ubiquitin-specific protease 10 (USP10) as a Taxinteractor in T-cells. Upon an exposure to arsenic, an oxidative stress inducer, USP10 was recruited into stress granules (SGs), which are the anti-stress machinery. USP10-knockout indicated that USP10, through augmenting formation of SGs, reduced reactive oxygen species (ROS) production and inhibited ROS-dependent apoptosis. Tax mutants and USP10-knockdown indicated that Tax inhibits arsenic-induced SG formation, stimulates ROS production and augments ROS-dependent apoptosis, and they are all dependent on interactions of Tax with USP10. These findings suggest that USP10 is a host factor that controls stress-induced ROS production and apoptosis in HTLV-1-infected T-cells. A clinical trial showed that a combination therapy containing arsenic is effective against some forms of ATL. Thus, these findings may also be relevant to chemotherapy against ATL.

Published: 7 January 2014

doi:10.1186/1742-4690-11-S1-052

Cite this article as: Takahashi et al: Stress granules inhibit apoptosis by reducing ROS production, but this phenomenon is nullified by HTLV-1 Tax. Retrovirology 2014 11(Suppl 1):052.

* Correspondence: masahiko@med.niigata-u.ac.jp

Division of Virology, Niigata University Graduate School of Medical and Dental Sciences, Niigata, Japan

Submit your next manuscript to BioMed Central and take full advantage of:

- Convenient online submission

- Thorough peer review

- No space constraints or color figure charges

- Immediate publication on acceptance

- Inclusion in PubMed, CAS, Scopus and Google Scholar

- Research which is freely available for redistribution 